\title{
IMPACT OF SEA RECLAMATION ON ZOOBENTHIC COMMUNITY IN ADJACENT SEA AREA: A CASE STUDY IN CAOFEIDIAN, NORTH CHINA
}

\author{
SUO, A. N. ${ }^{12^{*}}-$ LIN, Y. ${ }^{1}-$ SUN, Y. G. ${ }^{1}$ \\ ${ }^{1}$ National Marine Environment Monitoring Center, Dalian, China \\ (phone/fax:+086-0411-84783313) \\ ${ }^{2}$ Key Laboratory of Sea Area Management Technology, SOA, Dalian, China \\ (phonelfax:+086-0411-84783718) \\ *Corresponding author \\ e-mail:san720@sina.com \\ (Received $28^{\text {th }}$ Oct 2016; accepted $28^{\text {th }}$ Feb 2017)
}

\begin{abstract}
Aimed to reveal impact of sea reclamation on zoobenthic community in adjacent area, Caofeidian in north China was chosen as a case in this paper. A total of 54 sample points were set in adjacent area of reclamation in 2004, 2005, 2007 and 2010, which stand for beginning, midway and ending phase of sea reclamation project. Community density, biomass, richness index and biodiversity index were used to describe changes of zoobenthic community in the course of sea reclamation. It is found that sea reclamation reduced the density of zoobenthic community in adjacent sea area with density value in 2010 being $16.15 \%$ of that in 2004 . The biomass of zoobenthic community in adjacent sea area had no obvious change, but biomass of sample points near the dam was bigger than that in farther sample points. Sea reclamation also reduced species richness index and biodiversity index of zoobenthic community in adjacent area. The species richness index decreased from 39 in 2004 to 23 in 2010, while the Shannon-Weiner diversity index $\mathrm{H}^{\prime}$ decreased from 2.89 in 2004 to 1.55 in 2010. This impact implied that sea reclamation had changed sediment environment partly, so the structure of zoobenthic community had not changed completely.
\end{abstract}

Keywords: community structure; marine ecology; biodiversity; ecological assembly; macroinvertebrates

\section{Introduction}

As one of the three major ecosystems in the world, marine ecosystem plays an important role in conserving global biodiversity and safeguarding earth life system. The zoobenthic community inhabited in sediment of marine is one of main biological group in marine ecosystem. It provides food for migration birds and maintains stability of the coastal wetland food web for their special function in mass cycling and energy flow in marine ecosystem (Boer and Prins, 2002; Paz et al., 2008) The zoobenthos is also fishery resource for human food supply.

Sea reclamation not only completely covers natural marine original habitat of all biological community, but also changes hydrological process, sediment and sea bed relief of adjacent sea area, affecting the structure and biodiversity of biological community inhabited in the field (Liu et al., 2010; Serif et al., 2013; Suo et al., 2015). The impacts of 
sea reclamation on marine ecosystem and biology have been addressed by many scientists (Drake and Arias, 1997; Hu et al., 2008; Xu et al., 2013). For example, Shin and Mikio (2002) reported that Isabaya bay enclosure caused large-scale death of marine benthic bivalves and development of freshwater bivalve. Gao et al. (2009) studied the impact of sea area enclosure on fishery resources. Whereas Yuan and Lou (2001) documented the impact of fishpond enclosure on structure and biodiversity of zoobenthic community in tidal flat. Ge et al. (2005) studied the difference of mcro-zoonbenthic community in the enclose ponds which were built in different time. Ni and Qin (2003) found species richness, density, biomass and diversity of zoobenthic community all decreased obviously after the sea areas enclosed for agriculture pond. In spite of numerous studies above mentioned, the impact of sea reclamation on zoobenthic community in adjacent sea area is not documented to our knowledge. Given the importance of zoobenthic community in marine food chain and the economic value of their fishery resources, the study on the impact of sea reclamation on zoobenthic community has academic and practical implication. To disclose the impact of sea reclamation on adjacent marine zoobenthic community, Caofeidian in north China is chosen as a case in this paper.

\section{Study area}

Caofeidian $\left(E 118^{\circ} 28^{\prime} 40^{\prime \prime} \sim 118^{\circ} 34^{\prime} 0^{\prime \prime}, \mathrm{N} 38^{\circ} 54^{\prime} 0^{\prime \prime} \sim \mathrm{N} 39^{\circ} 05^{\prime} 0^{\prime \prime}\right)$ is located in north China of Tangshan city, Hebei province and in the northeast of Bohai bay. The islands of Caofeidian, Yaotuo, Caomutuo, Getuo, Dongkengtuo and Shijiutuo distribute in the seaside of the beach and running in the direction of northeast to southwest, forming the coastal sandy dam band with the distance varying from several hundred meters to more than 10 kilometers. An extensive shallow intertidal zone is developed between the dam band and coastal line. The intertidal zone above $0 \mathrm{~m}$ depth contour is about $17500 \mathrm{hm}^{2}$ in surface area and forms the important component of Luan river estuary and delta. The sediment in the intertidal zone are mainly fine sandy, typical of muddy beach. The complex tidal flat relief gives rise to various types of habitat and rich marine biodiversity, 47 phytoplankton species from 17 families, 64 zooplankton species of belonging to 12 categories, 53 benthic species and 27 fish species are found in this area.

\section{Sampling and analysis methods}

\section{Sea areas reclamation and its process}

According to the overall development planning of local government, sea reclamation of $31,000 \mathrm{hm}^{2}$ sea areas, is executed from 2004 to 2030. Satellite remote sensing images of Landsat TM and Landsat ETM, which were obtained in June 2004, September 2005, December 2007 and October 2010, were used to dynamically monitor the process of sea reclamation using monitoring methods referred to Moffett et al. (2015). No sign of sea reclamation is visible in June 2004, whereas the areas of reclamation reached $3032.60 \mathrm{hm}^{2}$ 
in September 2005, 8313.70hm ${ }^{2}$ in December 2007 and $19563.20 \mathrm{hm}^{2}$ in October of 2010, respectively. From then on, large-scale sea reclamation was almost stopped. For the convenience of analysis, the years of 2005, 2007 and 2010 are used as the mark point of beginning, midway and ending phase of sea reclamation in Caofeidian.

\section{Sampling methods}

According to the characteristic of sea reclamation engineering, 54 sites (10 for June 2004, 12 for July 2005, 10 for July 2007 and 22 for August 2010) were set in adjacent sea areas of sea reclamation to investigate the change of zoobenthic community in the course of sea reclamation in Caofeidian (Figure 1). A silt sampler with a size of $33 \mathrm{~cm} \times 30 \mathrm{~cm} \times 20 \mathrm{~cm}$. was made by iron for sediment and zoobenthos sampling. Sampling was carried out in low tide and sampling depth was set to $20 \mathrm{~cm}$ with 5 replicas for each site. The zoobenthic specimens were sifted by a sieve with mesh size of $1.0 \mathrm{~mm}$. All zoobenthic specimens were kept in $10 \%$ formalin and taken back to laboratory to identify and weigh. More details about sampling and test for zoobenthic specimens are given in $<$ sea investigation regulation $>>(\mathrm{GB} / \mathrm{T} 12763.6-2007)$.

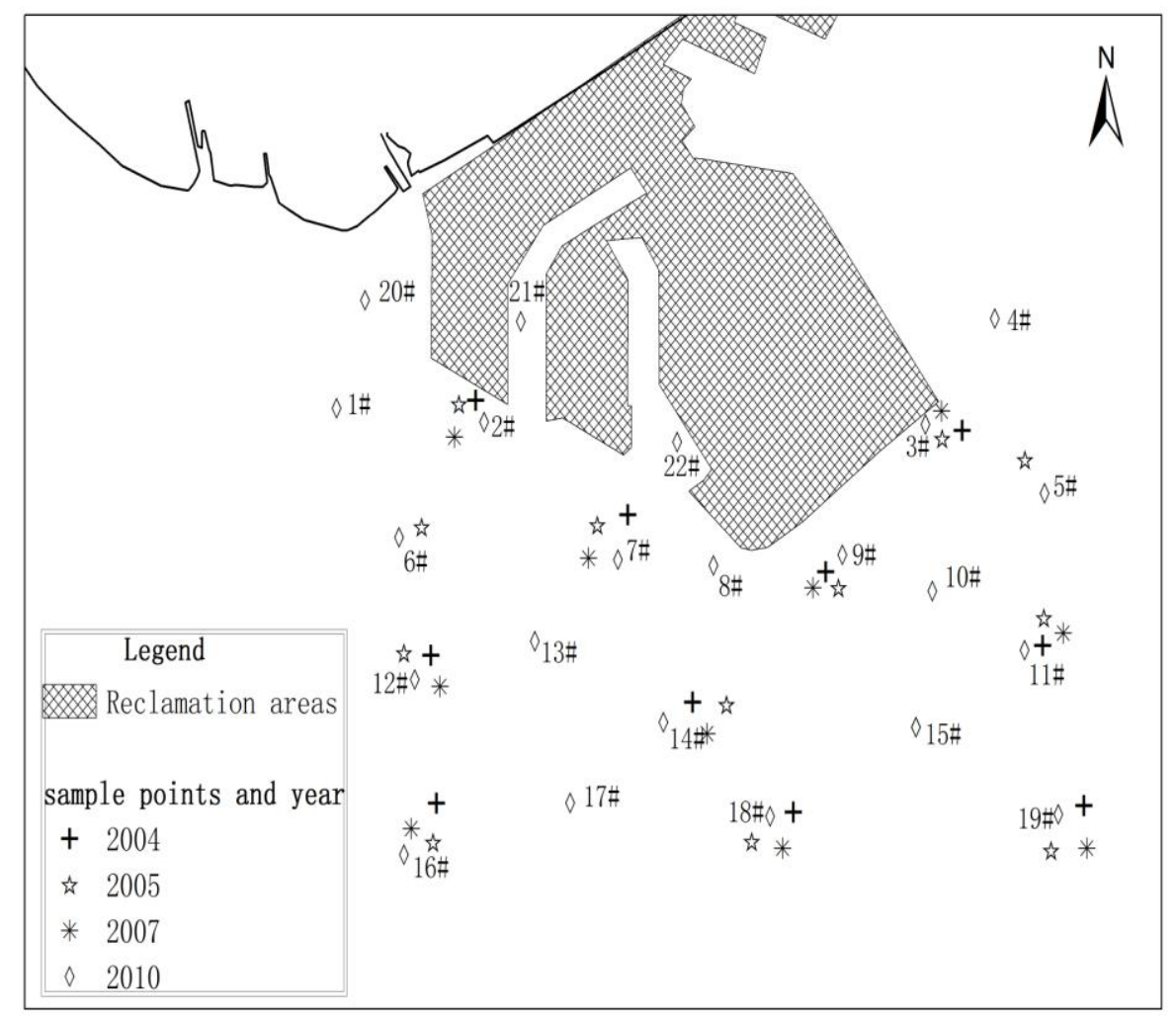

Figure 1. Sampling points of investigation in adjacent sea field of reclamation in Caofeidian Analysis methods 
The number of species identified in the 5 samples for each site was used to estimate zoobenthos species richness by simple summing method. The density and biomass of 5 samples was averaged to estimate their corresponding value for each site. The ratio of dry biomass to wet biomass is 1:5. The species whose individual number accounts for more than $20 \%$ of the total individual number is treated as dominant species. The community density, biomass, Shannon-Wiener biodiversity index and species richness index were calculated as follow to describe change of zoobenthic community in the course of sea reclamation.

$$
\begin{gathered}
p_{i}=a_{i} \\
B_{i}=\sum_{j=1}^{s} b_{j} \\
H^{\prime}=-\sum_{i=1}^{S} P_{i} \ln P_{i} \\
\mathrm{~F}=\mathrm{S}
\end{gathered}
$$

Where $p_{i}$ is density of zoobenthic community in the unit of ing $\cdot \mathrm{m}^{-2}$ in site $i$, whereas $\mathrm{a}_{\mathrm{i}}$ is the number of zoobenthos in site $\mathrm{i}$. Bi is the biomass of zoobenthic community in the unit of $\mathrm{g} \cdot \mathrm{m}^{-2}$ in site $\mathrm{i}$, whereas $b_{\mathrm{j}}$ is the biomass of species j. $\mathrm{H}^{\prime}$ is Shannon-Wiener biodiversity index of zoobenthic community, $\mathrm{P}_{\mathrm{i}}$ is ratio of individual number of species $\mathrm{i}$ of zoobenthic community, $\mathrm{F}$ is specie richness index and $\mathrm{S}$ is the species number of zoobenthic community.

\section{Result analysis}

\section{Community structure of zoobenthos before sea reclamation}

39 species of zoobenthos were found in June 2004 before sea reclamation, which include 29 species of Annelida, 12 species of Mollusca, 4 species of Arthropoda, 2 species of Echinoderm and 1 specie of Coelenterate and Platyhelminth. The density of zoobenthos ranged from $40 \mathrm{ing} \cdot \mathrm{m}^{-2}$ to $560 \mathrm{ing} \cdot \mathrm{m}^{-2}$, with the average value being 213.30 ing $\cdot \mathrm{m}^{-2}$. The common species were Moerella iridescens, Lumbrineris, Nassarius succinctus and Terebra koreana. The biomass of zoobenthos ranged from $1.23 \mathrm{~g} \cdot \mathrm{m}^{-2}$ to $54.29 \mathrm{~g} \cdot \mathrm{m}^{-2}$. Dominant species of biomass were Acanthomysis longirostris, Nassarius succinctus, Dugesiajaponica and Goniada japonica.

\section{Impact of sea reclamation on density of zoobenthic community}

The density change of zoobenthic community in adjacent sea areas in four different periods of sea reclamation is shown in Figure 2. It is clear that the density of zoobenthic community linearly decreased with reclamation area increase. The density of zoobenthic community was biggest in June 2004 before sea reclamation with the value of 213.30 ing $\cdot \mathrm{m}^{-2}$ and then reduced to $172.22 \mathrm{ing} \cdot \mathrm{m}^{-2}$ in July 2005 when sea reclamation expanded to $3032.60 \mathrm{hm}^{2}$. With the rapid expanding of sea reclamation to $8313.70 \mathrm{hm}^{2}$, 
the density continued to drop to $74.0 \mathrm{ing} \cdot \mathrm{m}^{-2}$ in July 2007 which is followed by $35.40 \mathrm{ing} \cdot \mathrm{m}^{-2}$ in August 2010 when the sea areas reclamation reached $19563.20 \mathrm{hm}^{2}$.

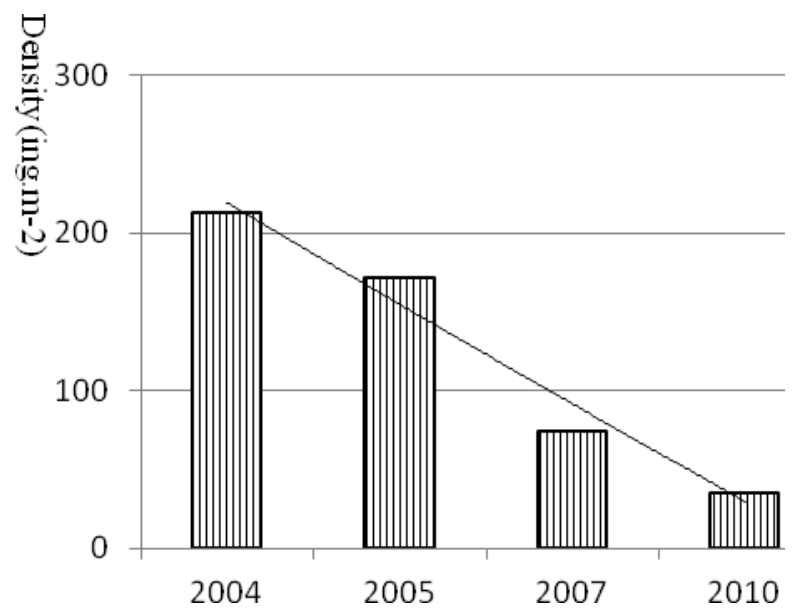

Figure 2. Change of density for zoobenthic community in adjacent field in reclamation process

\section{Impact of sea reclamation on biomass of zoobenthic community}

The biomass of zoobenthic community fluctuated with no obvious trend in the process of sea reclamation (Figure 3). It was $17.83 \mathrm{~g} \cdot \mathrm{m}^{-2}$ in June 2004 before sea reclamation and decreased to $16.0 \mathrm{~g} \cdot \mathrm{m}^{-2}$ in July 2005 at beginning phase sea reclamation. The biomass increased again to $21.79 \mathrm{~g} \cdot \mathrm{m}^{-2}$ in July 2007 in middle phase of sea reclamation. And it further increased to $24.50 \mathrm{~g} \cdot \mathrm{m}^{-2}$ in August 2010 when sea reclamation ended.

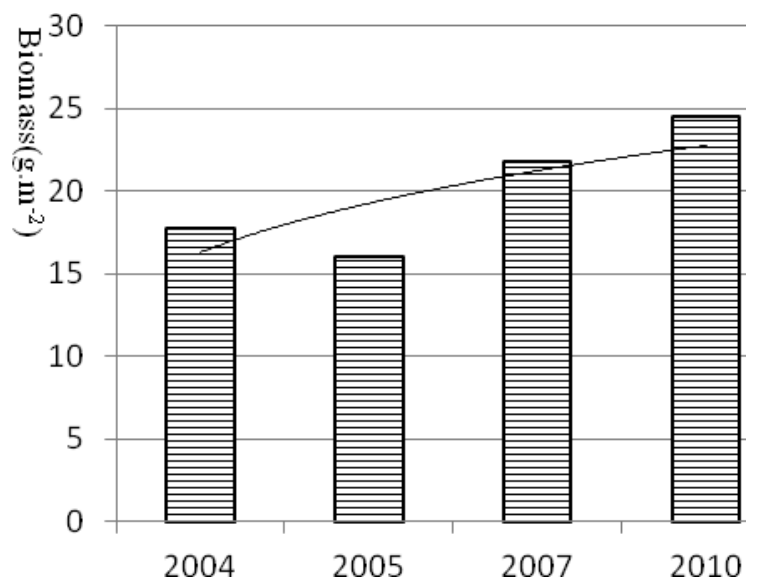

Figure 3. Change of biomass for zoobenthic community in adjacent field in reclamation process

A scatter diagram was drawn for biomass of 22 sites investigated in August 2010 to further reveal the influence of sea reclamation on biomass of zoobenthic community (Figure 4). Where horizontal axis stands for distance of sample site to reclamation dams. 
It is found that zoobenthic biomass for a site increased with its distance to the reclamation dams. The biomass of zoobenthos for site $1 \#(11.04 \mathrm{~km}$ distance away from reclamation dams) and site 5\# (10.40 km distance away from reclamation dams) were 56.10 and 29.20 $\mathrm{g} \cdot \mathrm{m}^{-2}$ in, respectively. In contrast, the biomass of zoobenthos in site $3 \#$ ( $88 \mathrm{~m}$ distance away from reclamation dams) was only $3.50 \mathrm{~g} \cdot \mathrm{m}^{-2}$ and that in site $2 \# 1.55 \mathrm{~km}$ distant away from reclamation dams was $14.10 \mathrm{~g} \cdot \mathrm{m}^{-2}$.

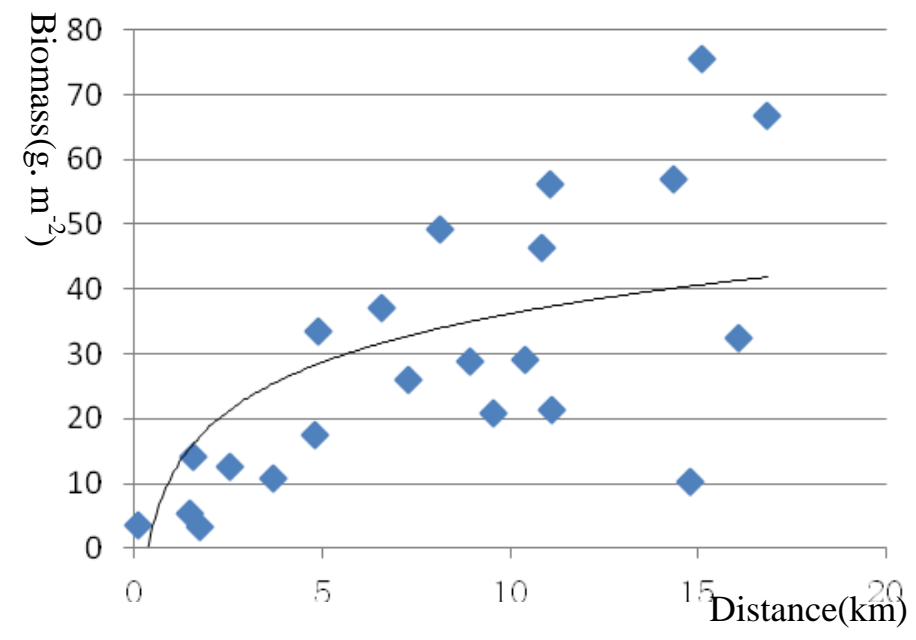

Figure 4. Relationship between the biomass of benthic community and distance from the dams

\section{Impact of sea reclamation on species diversity of zoobenthic community}

Figure 5 shows the change of community structure of zoobenthos in four different periods of sea reclamation. It is found that Annelida and Mollusca are dominant group in zoobenthic community in study area, but the species number changed greatly in different periods of sea reclamation. For example, the Annelida had 19 species in 2004 before sea reclamation, and reduced to 3 species in 2005 and then rebounded to 29 species in 2007 in the middle of sea reclamation, and lowered again to 7 species in 2010 when sea reclamation finished. The echinoderm had 2 species in 2004, 1 species in 2005, 3 species in 2007 and 2 species in 2010 with much smaller fluctuation.

The dominant species of different periods are listed in Table 1. Moerella iridescens, Lumbrineris, Nassarius succinctus and Terebra koreana dominated the zoobenthic community in 2004 before sea reclamation. They changed to Musculus senhousia and Ruditapes philipinarum in 2005 in the beginning phase of sea reclamation. And the dominant species converted to Sternaspis scutata, Moerella jedoensis, Mactra chinensis, Amphipholis kochii and Temnopleurus toreumaticus in 2007 when sea reclamation was half-way. Mactra chinensis, Moerella jedoensis and Lumbrinereis heteropoda dominated the zoobenthic community in the end phase of reclamation.

The change of Shannon-Weiner index and species richness index for zoobenthic community in four different periods is shown in Table 1. The Shannon-Weiner index $\mathrm{H}^{\prime}$ was the biggest with the value of 2.89 in 2004 before sea reclamation. It reduced to 1.92 
in 2005 , and 1.84 in 2007. It came down to 1.55 in 2010 . The species richness index was 39 in July 2004 before reclamation and reduced to 22 in July 2005. It increased to 53 in July 2007 and reduced again to 23 in August 2010. This indicates that sea reclamation not only influence the structure of zoobenthic communities in the adjacent sea areas, but also exert a certain impact upon the formation of population number of different species, thereby leading to continuous reduction in species diversity index of zoobenthic community.

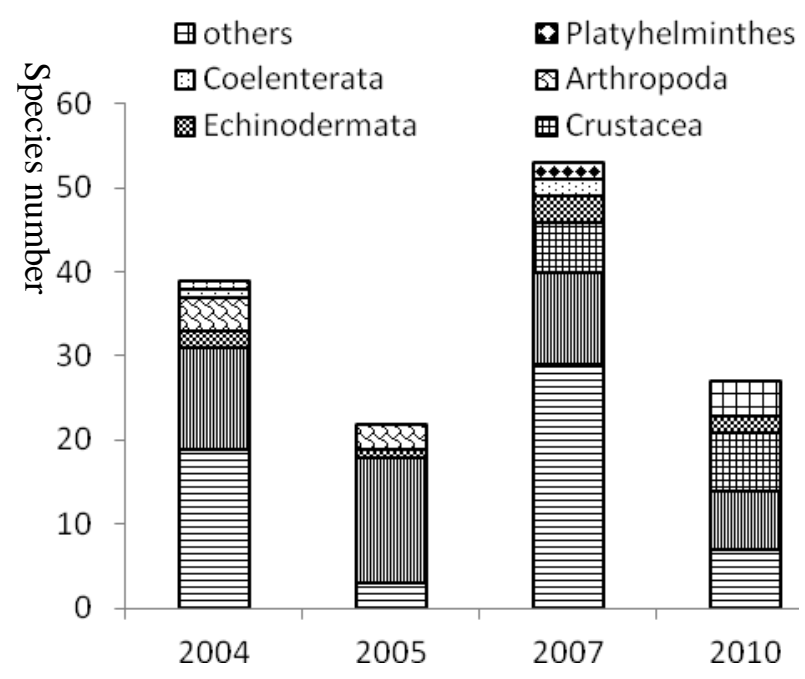

Figure 5. Change in the structure of benthic communities in the course of Caofeidian sea area reclamation

Table 1. Change of biodiversity for benthic communities in the adjacent waters of sea areas reclamation

\begin{tabular}{|c|c|c|c|}
\hline Year & $\begin{array}{l}\text { Diversity } \\
\text { index }\end{array}$ & $\begin{array}{l}\text { Richness } \\
\text { index }\end{array}$ & Dominant species \\
\hline 2004 & 2.89 & 39 & $\begin{array}{l}\text { Moerella iridescens, Lumbrineris, Nassarius succinctus, } \\
\text { Terebra koreana }\end{array}$ \\
\hline 2005 & 1.92 & 22 & Musculus senhousia, Ruditapes philipinarum \\
\hline 2007 & 1.84 & 53 & $\begin{array}{l}\text { Sternaspis scutata, Moerella jedoensis, Mactra } \\
\text { chinensis, Amphipholis kochii, Temnopleurus } \\
\text { toreumaticus }\end{array}$ \\
\hline 2010 & 1.55 & 23 & $\begin{array}{l}\text { Mactra chinensis, Moerella jedoensis, Lumbrinereis } \\
\text { heteropoda }\end{array}$ \\
\hline
\end{tabular}

\section{Discussion}

The seabed sediment is the main habitat for zoobenthic community. The species richness, density and biomass of zoobenthic community vary greatly with the sediment condition (Li et al., 2006a, 2006b; Gu et al., 2011). Sand and silt filled for sea reclamation all pumped from sediment of adjacent field seabed in Caofeidian. Plenty of sand and silt pumped had changed seabed relief in adjacent sea areas. Gong et al. (2012) reported 
sediment cut down $0.50 \mathrm{~m} \sim 0.80 \mathrm{~m}$ depth within range of $500 \mathrm{~m}$, and cut down $0.20 \mathrm{~m} \sim 0.40 \mathrm{~m}$ depth in range of $500 \mathrm{~m}$ to $1000 \mathrm{~m}$ distance in south adjacent sea areas of reclamation areas. While sediment silted up $0.10 \mathrm{~m} \sim 0.60 \mathrm{~m}$ depth within range of $800 \mathrm{~m}$ in west adjacent sea areas and silted up $0.70 \mathrm{~m}$ in local areas in east adjacent in Caofeidian. Hou et al. (2013) documented that sediment descend was $1.0 \mathrm{~m} 2.0 \mathrm{~m}$ in total in adjacent sea area in Caofeidian, it was bigger in west adjacent field than that in east adjacent, and reached $5.0 \mathrm{~m} \sim 10.0 \mathrm{~m}$ depth in local areas. Zhang and Wang (2006) studied scour and silting of adjacent sea areas in Caofeidian in period of 2004-2009, and concluded that the cut down of sediment in adjacent sea areas was mainly drove by desilt and sand pumping (Lou et al., 2007). Plenty of sand and silt pumping from adjacent sea area in Caofeidian reclamation process not only destroyed habitat condition of seabed relief for zoobenthic community, but also changed grain size of surface sediment by suspended sands deposition and flowing sand silting up. Some studies also certified that grain size of sediment distributed from fine grain size zone to coarse grain size zone and back to fine grain size zone in space, the coarse grain size zone is just fields where plenty of sand and silt pumped.

The research by Han et al. (2001, 2004) showed that the negative relationship exist between species richness of zoobenthic community and grain size of sediment. Guo et al. (2002) reported that species richness of the Copepods related negatively to average grain size of sediment in seabed. Change of habitat condition in adjacent sea areas in Caofeidian by plenty of sand and silt pumped not only reduced density of zoobenthic community, but also cut down the individual number of some species. These made these species were not found in the end phase of investigation. For example, The Arthropada has 4 species in 2004 and 3 species in 2005, but it was not fund in 2007 and 2010. The change of habitat condition drove by sea reclamation maybe created suitable condition for other species. The Crustacean species was not found in 2004 and 2005 in early phases of reclamation, but it appeared 6 species and 7 species in 2007 and 2010 in midway and end phase of reclamation, respectively. The Copepods was found in 2010, which was not appeared in preliminary investigation.

\section{Conclusion}

Sea areas reclamation is one of the major ways to supply new land for industrial and town development in coastal region. Extensive reclamation from sea give more space for social and economic development, it also exerts deep impact on the marine ecosystem at same time. This paper chose a typical large sea reclamation area in Caofeidian in north China to reveal the impact of sea areas reclamation on zoobenthic community in adjacent sea area by field investigation and sampling. The result show that sea reclamation reduced density of zoobenthic community in adjacent sea areas from the value 213.30ing $\cdot \mathrm{m}^{-2}$ in July 2004 to 35.40ing $\cdot \mathrm{m}^{-2}$ in August 2010. The sea reclamation not only reduced the individual number of zoobenthic community, but also led to disappearance of some species and reduced the species diversity of zoobenthic community in adjacent sea areas. Biodiversity Shannon-Weiner index of zoobenthic 
community was 2.89 in June 2004 before sea reclamation. It reduced to 1.55 in August 2010 in the end phase of reclamation and species richness index was also reduced from 39 in June 2004 to 23 in August 2010. The biomass of zoobenthic community in adjacent sea areas did not response to sea reclamation obviously in four different investigated periods, but the biomass of zoobenthos was smaller in sites nearer to dams than that sites farther to dams. Sea reclamation changed habitat condition of zoobenthic community in adjacent sea areas partly, but it did not change total habitat condition completely. So the structure of zoobenthic community did not change completely. Annelida and Mollusca were dominant species in total process of sea area reclamation in adjacent sea areas, Crustacean and Copepods were new species which did not found in early phase of reclamation.

Acknowledgements. This paper is funded by the Chinese Special Project for Marine Public (No.201105006) and National Natural Science Funds of China (No.41376120), the views expressed are authors' alone.

\section{REFERENCES}

[1] Boer, W. F., Prins, H. T.(2002): Human Exploitation and Benthic Community Structure on a Tropical Intertidal Flat. -Journal of Sea Research 48: 225-240.

[2] Drake, P., Arias, A. M.(1997): The Effect of Aquaculture Practices on the Benthic Macro-invertebrate Community of a Lagoon System in the bay of Cadiz (Southwestern Spain). -Estuaries 20: 677-688.

[3] Gao, W. B., Liu, X. Z., Duan, Y. Y., et al.(2009): Impact of Sea Reclamation on Fishery Resource in Liaoning Offshore and Corresponding Countermeasures. -Journal of Dalian Fisheries University 24:163-166.

[4] Ge, B. M., Bao, Y. X., Zheng, X. (2005): Macrobenthic Community Ecology of a Tidal Flat in Different Habitats and Creeks Dyked in Different Years. -Acta Ecologica Sinica 25(3):446-453.

[5] Gong, Z., Zhang, C. K., Tao, J. F., et al.(2012): Siltation in Harbor Basin after Reclamation in Caofeidian Silty Coast. -Oceanic Engineering 30(1):112-118.

[6] Gu, D. X., Liu, M. L., Liu, N.(2011): Community Component of Macrobenthos in Bohai bay and Their Relationships with Environmental factors. -Journal of Tianjin Agricultural University 18(3):5-8.

[7] Guo, Y. Q., Zhang, Z. N., Hui, F. H.(2002): Distribution Pattern of Abundance for Microbenthos in the Bohai sea. -Acta Oceanologica Sinica 24(6):1122-1129.

[8] Han, J., Zhang, Z. N., Yu, Z. S.(2001): Study on the Macrobenthic Abundance and Biomaa in Bohai sea. -Journal of Ocean University of Qingdao 31(6):889-896.

[9] Han, J., Zhang, Z. N., Yu, Z. S.(2004): Macrobenthic Community Structure in the Southern and Central Bohai sea, China. -Acta Ecologica Sinica 24(3):531-537.

[10] Hou, Q. Z., Ji, R. Y., Zuo, L. Q., et al.(2013): Remote Sensing Monitoring and Environmental Impact Analysis of Reclamation in Caofeidian sea area. -Hydro-Science 
and Engineering 3:1-7.

[11] Hu, Z. Y., Li, H. H., Bao, Y. X.(2008): Biodiversity Comparsion of Macrobenthic Communities at Tidal Flat of Lingkun island. -Acta Ecologica Sinica 28(4):1498-1507.

[12] Li, B. Q., Li, Z. X., Wang, H. F., et al.(2006a): Species Diversity of Macrobenthic Mollusk Fauna in Jiaozhou bay. Shandong. -Biodiversity Science 14(2):136-144.

[13] Li, Z. X., Li, B. Q., Wang, H. F., et al.(2006b): Macrobenthic Community of the Intertidal Zone of Jiaozhou bay. -Acta Zoologica Sinca 52(3): 612-618.

[14] Liu, S. X., Ma, Y. Y., Bian, Z. H.(2010):Assessment Methods of Effect of Sea Reclamation on Ecology and Environment. -Marine Bulletin 29(6):707-711.

[15] Lou, Y. J., Zuo, L. Q., Ji, R. Y., et al.(2007): Effect of Development of Caofeidian Harbor Area in Bohai bay on Hydrodynamic Sediment Environment. -Advances in Water Science 18(6):393-400.

[16] Moffett, K. B., Nardin, W., Silvestri, S., et al. (2015): Multiple stable states and catastrophic shifts in coastal wetlands: progress, challenges, and opportuni- ties in validating theory using remote sensing and other methods. -Remote Sens 7(10):184-226.

[17] Ni, J. R., Qin, H. P.(2003): Influence Evaluation for Sea Reclamation Engineering on Loss of Wetland Habitat in Tidal Flat. -Journal of Environmental Science 23(3):345-349.

[18] Paz, L., Neto, J. M., Marques, J. C.(2008): Response of Iintertidal Macrobenthic Communities to Long Term Human Induced Change in the Eoestuary(Asturias, Spain): Implication for Environmental Management. -Marine Environment Research 66:288-299.

[19] Serif, H., Cigdem, C. H., Cigdem, K., et al.(2013): Analyzing landscape change and urban sprawl in a Mediterranean coastal landscape: A case study from Izmir, Turkey. -Journal of Coastal Research 29(2):301-310.

[20] Shin, I. S., Mikio, A.(2002): Ecological and Paleoecological Implications of the Rapid Increase and Decrease of an Introduced Bivalve Potamocorbula sp. after the Construction of a Reclamation dike in Isahaya Bay, western Kyushu. -Japan Palaeogeography Palaeoclimatology 185:369-378.

[21] Suo, A. N., Cao, K., Zhao, J. H.(2015): Study on impacts of sea reclamation on fish community in adjacent waters: a case in Caofeidian, North China. -Journal of Coastal Research 73(SI):183-187.

[22] Xu, M. B., Jiang, F. J., Lai, J. X., et al. (2013): Structure of Macrobenthic Community and its Ecological Characteristics Analysis in Adjacent Sea Field of Reclamation Ergineering in Qinzhou bay. -Guangxi Science 12(1):69-77.

[23] Yuan, X. Z., Lou, J. J.(2001): Preliminary Study on Macrobenthic Community of the Creek in the Tidal Flat of the Changiiang Estuary. -Zoological Research 22(3):211-215.

[24] Zhang, W., Wang, B.(2006): Numerical Simulation of Shoal Reclamation in Caofeidian. -Jouranl of Hehai University(Natural edition) 34:194-199. 